\title{
Annual Variation in Habitat Use by White-footed Mice, Peromyscus leucopus: The Effects of Forest Patch Size, Edge and Surrounding Vegetation Type
}

\author{
Christine S. Anderson ${ }^{1}$, Douglas B. Meikle ${ }^{2}$, Alan B. Cady ${ }^{2}$, and Robert L. Schaefer ${ }^{3}$ \\ ${ }^{1}$ Present address: Department of Evolution, Ecology, and Organismal Biology, The Ohio State University, Columbus, Ohio \\ 43210 USA. e-mail: anderson.1309@osu.edu; formerly C. Schandorsky; corresponding author. \\ ${ }^{2}$ Department of Zoology, Miami University, Oxford, Ohio 45056 USA \\ ${ }^{3}$ Department of Mathematics and Statistics, Miami University, Oxford, Ohio 45056 USA
}

\begin{abstract}
Anderson, Christine S., Douglas B. Meikle, Alan B. Cady, and Robert L. Schaefer. 2006. Annual variation in habitat use by Whitefooted Mice, Peromyscus leucopus: The effects of forest patch size, edge and surrounding vegetation type. Canadian Field-Naturalist 120(2): 192-198.
\end{abstract}

White-footed Mice (Peromyscus leucopus) were trapped for two years in the exterior matrix, edge, and interior forest habitat sections of six forests patches in a fragmented agricultural landscape. We used data on the capture locations of $P$. leucopus individuals from the two years, which differed in rainfall (i.e., summer of 2000 with $50 \%$ more rain than summer of 1999), to assess how patch size, edge habitat, and surrounding habitat type influence habitat use and movements in populations of this forest habitat generalist. We found that the proportion of individuals subsequently captured in the forest edge from the exterior was 16 times greater in the wet year than in the dry year and approximately twice as many P. leucopus were not subsequently recaptured from the exterior matrix in the dry year compared to the wet year. For each year, captures between habitats did not differ in relation to patch size, edge forest habitat, or exterior matrix type. These results illustrate the generalist habitat preferences of P. leucopus, but emphasize annual variation in their behavior and distribution.

Key Words: White-footed Mice, Peromyscus leucopus, forest patches, habitat preference, edge habitat, exterior matrix, Ohio, Indiana.

Human activities have led to a reduction and fragmentation of secondary-growth deciduous forests in North America, as well as changes in the quality of the remaining habitat (Yahner 1988; Fahrig 1997). The effects of fragmentation include those related to loss of connectivity among remnant patches, and increases in edge habitat, which both can cause local changes in abundance, distribution, and species' persistence (Andren 1994, 1997; Murcia 1995). In addition, the fragmentation of forested habitat results in the creation of forest patches that vary in size. Studies have shown that there are taxonomic differences in the relationship between animal population densities and patch area. Insects and birds generally show a positive relationship, likely due to an avoidance of edge habitat, which is greater in proportion in smaller patches (Connor et al. 2000). The majority of mammal species show fairly constant population densities with patch area, this follows the theory of island biogeography (Bowers and Matter 1997).

In contrast, investigators have found a consistent negative relationship between density of the White-footed Mouse (Peromyscus leucopus Rafinesque), a forest habitat generalist, and forest patch area (Nupp and Swihart 1996, 1998; Krohne and Hoch 1999; Mossman and Waser 2001; Schmid-Holmes and Drickamer 2001; Anderson et al. 2003; Anderson and Meikle 2006). Although resource availability may influence population dynamics of small mammals (e.g., Nupp and Swi- hart 1996), there are other factors that may be responsible for the negative density-area relationship. One possibility is that dispersal is inhibited from smaller forest patches due to lower habitat quality in the matrix than under continuous forest cover (Brown and Litvaitis 1995; Nupp and Swihart 1998; Krohne and Hoch 1999). We hypothesize in the current study that if inhibited dispersal results in the negative density-area relationship, then fewer P. leucopus should tend to move from the forest edge to the agricultural fields surrounding smaller compared to those surrounding larger forest patches.

In addition to patch area, another consequence of forest fragmentation is an increase in the proportion of edge habitat in the landscape since smaller forest patches have a greater edge: interior ratio than larger forest patches. Forest edges usually exhibit differences in microclimate, species composition, and vegetation structure compared to forest interiors (Harris 1988; Saunders et al. 1991). These difference may influence abundance and distribution of animal species. Studies have found that some forest animals may prefer forest edges while others may avoid those areas (Harris 1988; Saunders et al. 1991; Murcia 1995). However, there is debate as to whether P. leucopus prefers forest edge to forest interior habitat. Some investigators have reported greater densities of Peromyscus spp. near edges (Cummings and Vessey 1994; Boyne and Hobson 1998; Manson et al. 1999), possibly because 
vegetation in edge habitat has been shown to be structurally more complex compared to interior habitat (Cummings and Vessey 1994; Anderson et al. 2003). In contrast, others have found fewer mice and lower maternal survival and litter success in edge habitats, presumably because parasitism, predation and interspecific competition can be higher along edges (Matter et al. 1996; Morris and Davidson 2000; Wolf and Batzli 2001, 2004). Since there is no evidence to date of higher rates of predation on mice in forest edges, then we predict that mice may prefer the high quality vegetation in forest edges such that there would be higher recapture rates in forest edges than in forest interiors.

Another consequence of forest fragmentation is that forest patches are surrounded by a matrix of agriculture or residential development that may inhibit the movement of organisms (Fitzgibbon 1997; Collinge 1996). Even though the agricultural matrix surrounding forest patches may be considered "hostile" habitat for some species (Collinge 1996), generalists such as P. leucopus (Gottschang 1981) may disperse relatively easily (Lackey 1978) through row crop fields (Mossman and Waser 2001). However, it is not well understood whether matrix types (e.g., corn or pasture) differentially affect capture rates of White-footed Mice in the exterior matrix. M'Closkey and Lajoie's (1975) work suggests that $P$. leucopus may prefer corn over pasture because mice were absent from grasslands. Even though grasses may provide cover for mice from aerial predators, Getz (1961) also noted that individual Peromyscus avoided grassy sites under forest canopy (also see M'Closkey and Lajoie 1975) likely because it rustles as the mouse moves (Barnum et al. 1992). If surrounding habitat type influences movements of mice throughout the landscape, we predict that they may stay in or move into the surrounding matrix habitat at greater rates when the matrix is comprised of corn rather than pasture.

The purpose of this study was to use data on the first two captures of P. leucopus individuals in different habitats (i.e., exterior matrix, forest edge, and forest interior habitat) in small and large forest patches for two summers to test the hypotheses related to patch size, edge habitat, and surrounding habitat type as described above. In addition, we compared captures among habitats between two summers differing in rainfall amounts (i.e., one dry year and one wet year) because temporal variation in precipitation regulates rodent population dynamics (Lewellen and Vessey 1998). Utilizing data on habitat use instead of overall abundance, we assumed that if mice tended to prefer one habitat over another, then, on average, they would move into (or stay in) the preferred habitats in relatively high proportions. Since much of the work on the effects of forest fragmentation has been focused on birds, this study contributes to our understanding of how human-dominated landscapes influence habitat use and movements of populations of small mammals.

\section{Methods}

Study Area

Peromyscus leucopus were trapped in both 1999 and 2000 in the same three "small" ( 5-9 ha) and three "large" ( 110-150 ha) forest patches in a row-crop agricultural landscape covering approximately $144 \mathrm{~km}^{2}$ in SW Ohio and SE Indiana, USA (study area, 39 $51^{\prime} \mathrm{N}$, 84 $74^{\prime} \mathrm{W}$; Anderson and Meikle 2006; Table 1). We analyzed data from four transects of six Sherman ${ }^{\mathrm{TM}}$ live traps $(7.5 \times 7.5 \times 25.5 \mathrm{~cm})$ that were placed perpendicular to the center of one edge of each patch, with each transect beginning $20 \mathrm{~m}$ exterior to and extending $30 \mathrm{~m}$ into the patch (Figure 1). The transects and the traps in each transect were spaced $10 \mathrm{~m}$ apart, resulting in a $30 \mathrm{~m}$ by $50 \mathrm{~m}$ grid with a total of 24 traps at each forest patch. The eight traps in the agricultural field outside of each forest patch were considered "exterior" and the next eight traps were considered "edge". The eight traps inside the forest patch were considered "interior" traps. Based on our previous findings (Anderson et al. 2003) and corroborated by Burke and Nol (1998), the width of the edge habitat was defined based on typical edge floristic features. The surrounding habitat type in the exterior matrix was either pasture or corn fields (Table 1).

\section{Data collection}

Traps were set on 26 nights in each forest patch between June and September in 1999 and 2000 for a total of 7488 trap-nights. When a mouse was captured initially it was lightly anesthetized with halothane and a 12 mm AVID ${ }^{\circledR}$ microchip (PIT tag) was injected under the scruff of its neck. To distinguish between $P$. leucopus (primarily a woodland species) and $P$. maniculatus (primarily a grassland species), which are morphologically similar and overlap in the nonforested habitat within the study area, saliva samples were analyzed for the migration of the amylase enzyme with polyacrylamide gel electrophoresis (Aquadro and Patton 1980; Bruseo et al. 1999). We followed the protocol of Bruseo et al. (1999) with minor modifications.

Each patch was trapped for two consecutive nights every 5-7 $d$ and we recorded the date, identification number and location of every individual at every trapping event. Based on trap location we determined which habitat (i.e., exterior, edge, or interior) each individual was located in for its first capture and then where it was subsequently captured for its second capture event. It is possible that the length of time between any two capture events for a particular individual could be 24 hours apart or more. A fourth category for the subsequent capture was "not subsequently recaptured", which was used if the individual was not recaptured again after tagging. Only the first two capture events for each individual were analyzed so that each individual was included only once in the analysis to avoid pseudoreplication. In order to verify whether a mouse moving into a particular habitat reflects fidelity to this 
TABLE 1. Description of study sites and their location, size, and surrounding habitat type (i.e., exterior matrix habitat) in 1999 and 2000.

\begin{tabular}{|c|c|c|c|c|}
\hline \multirow[b]{2}{*}{ Patch names } & \multirow[b]{2}{*}{ Location } & \multirow[b]{2}{*}{ Size (ha) } & \multicolumn{2}{|c|}{ Surrounding habitat type } \\
\hline & & & 1999 & 2000 \\
\hline \multicolumn{5}{|l|}{ Small patches } \\
\hline ERC (Ecology Research Station) & Oxford, Ohio & 5 & pasture & pasture \\
\hline Indiana & Bath, Indiana & 8 & corn & corn \\
\hline Jericho & Oxford, Ohio & 9 & corn & corn \\
\hline \multicolumn{5}{|l|}{ Large patches } \\
\hline Bachelor Woods and Game Preserve & Oxford, Ohio & 150 & pasture & pasture \\
\hline Hueston Woods State Park & Preble/Butler Counties, Ohio & 200 & corn & pasture \\
\hline Reily Township & Reily, Ohio & 110 & corn & soybeans* \\
\hline
\end{tabular}

*This patch was not included for tests involving surrounding habitat type since it was the only patch with soybeans.

habitat shift, we also analyzed the data for the first year using all captures of all mice instead of the first two capture events only (i.e., 188 mice captured a total of 901 times) and found similar results (not presented), suggesting a permanence of habitat shifts. Although over winter survival was very low (i.e., four known individuals) between the two years of this study (Anderson 2004), we did not include those four individuals in the data set for the second year. Rainfall amounts from the Ohio Agricultural Research \& Development Center (OARDC) weather station on Miami University's Oxford campus (http://jrscience.wcp.muohio.edu/ van tagepro/latestweather.html) were totaled for each summer month (June - August) in 1999 and 2000. The OARDC is located within the center of the study area.

\section{Statistical analyses}

Data on the proportion of mice trapped for their second capture in the exterior, edge, or interior habitats, or not subsequently recaptured, based on the three initial capture habitats (i.e., exterior, edge, or interior) were compiled (see Table 2). The data set was analyzed with PROC CATMOD using chi-square tests to determine whether captures among habitats differed in relation to patch size, surrounding matrix type, and year (SAS 1999-2000). Subsets of the data were analyzed with PROC FREQ using either chi-square tests or Fisher's exact tests when sample size was small $(n<50$ or cells
Agricultural field

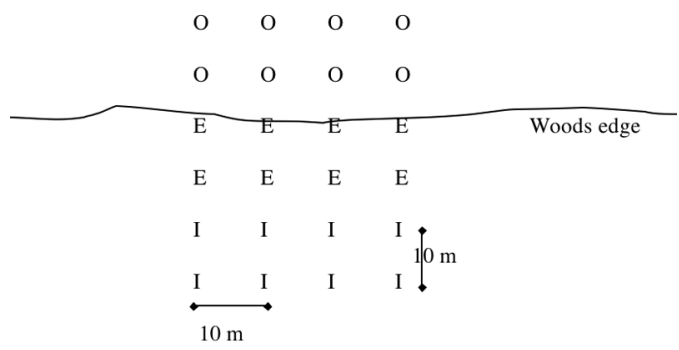

Forest Interior

FIGURE 1 . The trapping grid design for each of the forest patches in this study. The letter " $\mathrm{O}$ " denotes each outside (i.e., exterior) trap, the letter " $E$ " represents the eight edge traps, and the "I" denotes the interior trap locations.

with values < 5; SAS 1999-2000). Data from each year were analyzed separately (see Results; Table 2). In post hoc analyses, Fisher's exact tests and chi-square tests were used where appropriate (Moore and McCabe 1993) with a Bonferroni adjustment to the level of sig-

TABle 2. The habitat where each Peromyscus leucopus was trapped for its second capture based on where it was first captured in 1999 and 2000. Values are pooled across patch sizes and number of individuals and row percentages are given in parentheses.

\begin{tabular}{|c|c|c|c|c|}
\hline \multirow{2}{*}{$\begin{array}{l}\text { Habitat where first captured } \\
1999\end{array}$} & \multicolumn{4}{|c|}{ Habitat where subsequently (i.e., second) trapped } \\
\hline & Exterior & Edge & Interior & Not subsequently recaptured \\
\hline Exterior & $9(28 \%)$ & $1 \quad(3 \%)$ & $2(6 \%)$ & $20(63 \%)$ \\
\hline Edge & $6(14 \%)$ & $19(43 \%)$ & $10(23 \%)$ & $9(21 \%)$ \\
\hline Interior & $2 \quad(4 \%)$ & $8(15 \%)$ & $17(31 \%)$ & $27(50 \%)$ \\
\hline 2000 & Exterior & Edge & Interior & Not subsequently recaptured \\
\hline Exterior & $1 \quad(8 \%)$ & $6(50 \%)$ & $1 \quad(8 \%)$ & $4(33 \%)$ \\
\hline Edge & $(3 \%)$ & $18(46 \%)$ & $10(26 \%)$ & $10(26 \%)$ \\
\hline Interior & $(0 \%)$ & $7(13 \%)$ & $23(41 \%)$ & $26(46 \%)$ \\
\hline
\end{tabular}


nificance at $\alpha=0.05$ (Sokal and Rohlf 1981). An unpaired t-test was used to test for a difference in mean monthly rainfall in the summer (June - August) of 1999 compared to 2000 (Sokal and Rohlf 1981).

\section{Results}

Patch size did not influence captures of P. leucopus among habitats in either 1999 or 2000 (1999: $\chi_{3}^{2}=0.9$, $\left.P=0.8 ; 2000: \chi^{2}{ }_{3}=4.7, P=0.2\right)$. Hence, there was no difference in captures of mice among different habitats (i.e., exterior matrix, edge, or interior habitats, or not subsequently recaptured) for those individuals that had been initially trapped in edge habitat in small compared to large patches in either year (1999: Fisher's exact test, $n=44, P=0.5$; 2000: Fisher's exact test, $n=39, P=0.7)$. Data were pooled across patch sizes within each year for all other analyses (Table 2). The proportion of $P$. leucopus recaptured in edge habitat (i.e., both the first and second captures occurred in edge habitat) compared to the proportion recaptured in interior habitat did not differ in either year (1999: $\chi^{2}=1.4$, $\left.P=0.2 ; 2000: \chi^{2}{ }_{1}=0.2, P=0.6\right)$, suggesting that mice did not show a preference for edge or interior forest habitat. Surrounding habitat type (i.e., corn or pasture) did not influence the proportion of mice subsequently captured across different habitats that had been first captured in the edge in either year (1999: Fisher's exact test, $n=44, P=0.5$; 2000: Fisher's exact test, $n=33, P=0.2$ ). Likewise, surrounding habitat type did not affect subsequent captures across habitats for mice that had been first captured in the exterior matrix habitat in either year (1999: Fisher's exact test, $n=32$, $P=0.3 ; 2000$ : Fisher's exact test, $n=10, P=0.3$ ).

When captures between habitats in 1999 and 2000 were compared, P. leucopus first captured in the exterior were subsequently trapped in different proportions among habitats in 1999 compared to 2000 (Fisher's exact test, $n=44, P=0.002$ ); specifically, the proportion of individuals subsequently captured in the forest edge from the exterior was 16 times greater in 2000 $(6 / 12=50 \%)$ than in $1999(1 / 32=3 \%$; Fisher's exact test, $n=44, P=0.0008$; Table 2, Figure 2a). Likewise, a greater proportion of mice stayed in the exterior matrix compared to moving into the forest (edge and interior combined) in $1999(9 / 12)$ than in $2000(1 / 7$; Fisher's exact test, $n=20, P=0.02$ ). Approximately twice as many $P$. leucopus were not subsequently recaptured after their first capture in the exterior matrix in $1999(20 / 32=63 \%)$ compared to $2000(4 / 12=33 \%)$, although the test was not significant (Fisher's exact test, $n=44, P=0.1$; Figure $2 b$ ). Mean monthly rainfall amounts were over $50 \%$ higher in the summer (June-August) of 2000 (mean $\pm \mathrm{SE}=11.8 \pm 0.9 \mathrm{~cm}$ ) compared to $1999\left(5.3 \pm 1.0 \mathrm{~cm} ; t_{4}=4.7, P=0.009\right)$.

\section{Discussion}

Patch size

Studies have shown that populations of P. leucopus, unlike birds, insects, and most other mammals,

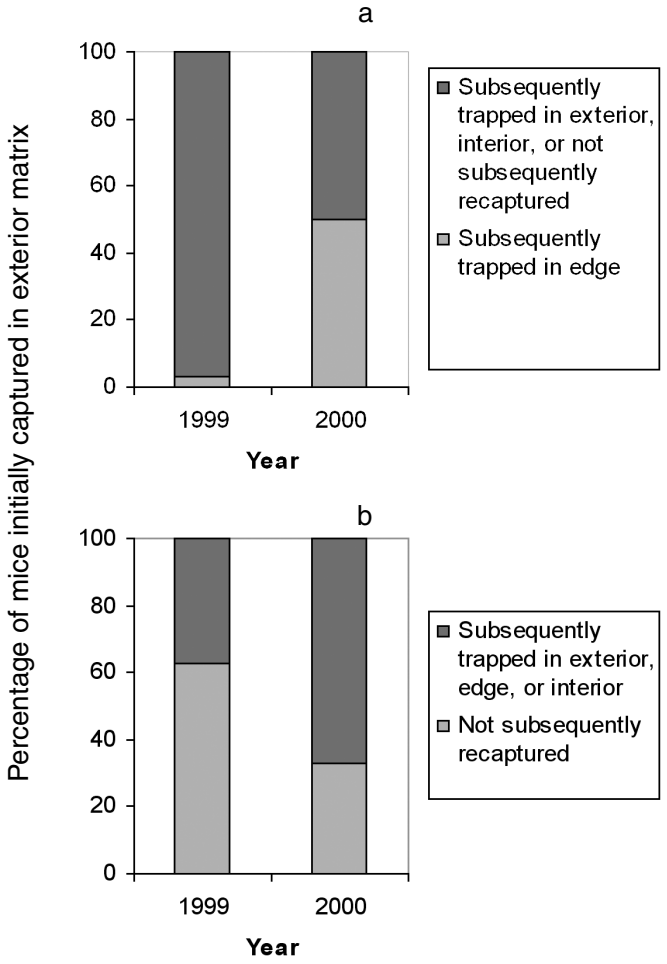

FIGURE 2. Percentage of mice (a) subsequently captured in forest edge habitat in 1999 compared to 2000 and (b) not subsequently recaptured in 1999 compared to 2000 (see Table 2 for sample sizes) that had been initially trapped in the exterior matrix habitat.

have greater densities in smaller forest patches (Nupp and Swihart 1998; Krohne and Hoch 1999; Anderson et al. 2003). One proposed mechanism to account for this negative density-area relationship is that habitat quality is lower in the exterior matrix than in woodland sites (Nupp and Swihart 1996; Krohne and Hoch 1999). Predation pressure may be elevated in the agricultural fields surrounding smaller patches because some predators may attain higher densities in a landscape with a variety of land uses (Brown and Litvaitis 1995). We predicted that fewer mice would move from the forest edge to the agricultural fields surrounding smaller than larger forest patches, but our results did not support the inhibited dispersal hypothesis. Diaz et al. (1999) found no difference in movements of Apodemus sylvaticus to the exterior in relation to patch size, whereas Krohne and Hoch (1999) found that P. leucopus populations in Indiana had lower dispersal rates from smaller patches, a factor that may have resulted in higher densities in those patches (Adler and Levins 1994). Nupp and Swihart (1996) concluded that both reduced dispersal and greater abundances of food contributed to the high densities of $P$. leucopus they observed in small forest woodlots. 
It is unclear why densities of P. leucopus tend to be higher in small forest patches (Anderson and Meikle 2006). One possibility is that immigration rates are in fact greater into smaller forest patches, resulting in higher densities in those patches (Bowman et al. 2002). However, we did not find that movements from exterior to the edge or interior habitats were greater in smaller than larger patches in this study. If smaller and larger forest patches do not vary in emigration and immigration rates, as our data suggest, then a second possibility is that other factors, such as greater food abundance or cover from predators, may have resulted in greater abundances of mice in smaller patches or in particular the edges of small patches (Nupp and Swihart 1996; Diaz et al. 1999; Anderson et al. 2003; Anderson and Meikle 2006). A third possibility is that lower densities in larger patches may be the result of mice dispersing to low density regions within the heterogeneous forest patch to alleviate high densities, with fewer sites likely present in smaller forest patches (Krohne and Burgin 1990; Krohne and Hoch 1999).

\section{Edge habitat}

Differences in species composition and vegetation structure in forest edges compared to forest interiors, regardless of patch size; may influence the distribution of small mammals within forest fragments (Matlack 1994; Collinge 1996). Currently, there are conflicting reports about the effects of edge habitat on the abundance and distribution of White-footed Mice (e.g., Cummings and Vessey 1994; Anderson et al. 2003; Wolf and Batzli 2004). We found that P. leucopus were recaptured in the same proportion in forest edge compared to forest interior habitat in either year. Our data on initial and second capture habitat locations support those studies that reported no difference in the relative abundance of mice in those two habitats (Heske 1995; Nupp and Swihart 1996, 1998). This result is somewhat surprising since forest edge habitats have been shown to have greater structural complexity in the understory vegetation compared to edge habitat (Anderson et al. 2003) and White-footed Mice have been shown to prefer areas with more plant cover (Drickamer 1990). One explanation could be that mice are not moving into edge habitat but are already present in high abundances with small territory sizes. Perhaps once territories are established in early spring, when movements among high (i.e., edge) and low quality (i.e., interior) habitats are negligible due to competitive exclusion.

\section{Surrounding habitat type}

Types of vegetation in the surrounding matrix habitat may differentially affect the population dynamics of rodent species in a fragmented landscape. For example, Wolf and Batzli (2004) found that predation risk for $P$. leucopus was higher at edges adjacent to restored prairies than at edges adjacent to agricultural fields. Our findings showed that $P$. leucopus moved in similar proportions from the forest edge into two different matrix habitat types (i.e., corn and pasture). This is in contrast to studies that have found that P. leucopus tend to avoid grassy habitats and can be found in corn fields at densities as high as those in woodlots (Getz 1961; M'Closkey and Lajoie 1975; Wegner and Merriam 1979, 1990). Mice in our study sites may have simply responded to the seasonal presence of cover and not to the type of cover (Cummings and Vessey 1994). Henein et al. (1998) designed a simulation model illustrating flexible and opportunistic responses of $P$. leucopus to landscape structure and connectivity via an expansion of their use of corn and small grain fields. Similar results have been found for A. sylvaticus, a mouse species also described as a habitat generalist (Garcia et al. 1998; Kozakiewicz et al. 1999).

\section{Annual variation}

Rainfall may impact rodent populations directly by influencing their reproductive status and survival, or indirectly in relation to changes in food sources and vegetative cover from predators (Kaufman et al. 1995; Kesner and Linzey 1997). Monthly rainfall data showed that totals in the summer of 2000 were almost $50 \%$ greater than in 1999. For mice initially captured in the exterior matrix habitat, we found that a greater proportion moved to the edge habitat and more were subsequently recaptured in the exterior matrix in the wet year compared to the dry year. If rainfall influenced patterns of capture among habitats, one explanation is that in 1999 (i.e., the dry summer) a higher proportion of mice were not subsequently recaptured from the exterior matrix habitat because they died due to poor conditions, or moved throughout the landscape in search of other better quality habitats (Kesner and Linzey 1997; Lidicker and Stenseth 1992). In 2000, the shrub and herbaceous layers in the forest habitat may have had more or higher-quality food sources compared to the exterior matrix as a consequence of rainfall which caused an influx of mice to the forest habitat (Parmenter and MacMahon 1983; Bowers and Dooley 1999; Hutchinson et al. 1999). Our results illustrate the generalist habitat preferences of $P$. leucopus but emphasize annual variation in their distribution within the forest and surrounding habitats. However, year-to-year differences in patterns of habitat use may be influenced by a number of variables, and a longer-term study would help to elucidate those factors (Kesner and Linzey 1997).

\section{Acknowledgments}

We thank the landowners for permission to use study sites, in addition to the Ohio Department of Natural Resources, Hueston Woods State Park, Miami University's Natural Areas Committee and Miami University's Ecology Research Center. We thank J. Bruseo, M. Spritzer, S. Vessey, and three anonymous reviewers for their valuable advice. K. Fielitz, J. Gliha, C. Harrison, R. Lim, A. Lohrey, D. Markert, M. Tarbox, K. Wolfe and especially R. Young provided valuable support in the laboratory and in the field. This work was 
supported with funding from Sigma Xi and the Department of Zoology at Miami University. Research on live animals was performed in a humane manner and was approved by the Institutional Animal Care and Use Committee (IACUC) at Miami University (protocols \#430 and \#467).

\section{Literature Cited}

Adler, G. H., and R. Levins. 1994. The island syndrome in rodent populations. Quarterly Review of Biology 69: 473490.

Anderson, C. S. 2004. Effects of forest fragmentation on the abundance, distribution, and population genetic structure of white-footed mice (Peromyscus leucopus). Ph.D. dissertation, Miami University, Oxford, Ohio, USA. 144 pages.

Anderson, C. S., A. B. Cady, and D. B. Meikle. 2003. Effects of vegetation structure and edge habitat on the density and distribution of white-footed mice (Peromyscus leucopus) in small and large forest patches. Canadian Journal of Zoology 81: 897-904.

Anderson, C. S., and D. B. Meikle. 2006. Annual changes in structural complexity of understory vegetation and relative abundance of Peromyscus leucopus in fragmented habitats. Acta Theriologica 51: 43-51.

Andren, H. 1994. Effects of habitat fragmentation on birds and mammals in landscapes with different proportions of suitable habitat: a review. Oikos 71: 355-366.

Andren, H. 1997. Habitat fragmentation and changes in biodiversity. Ecological Bulletins 46: 171-181.

Aquadro, C. F., and J. C. Patton. 1980. Salivary amylase variation in Peromyscus: use in species identification. Journal of Mammalogy 61: 703-707.

Barnum, S. A., C. J. Manville, J. R. Tester, and W. J. Carmen. 1992. Path selection by Peromyscus leucopus in the presence and absence of vegetation cover. Journal of Mammalogy 73: 797-801.

Boyne, E. M., and K. A. Hobson. 1998. The effects of habitat fragmentation by forestry and agriculture on the abundance of small mammals in the southern boreal mixedwood forests. Canadian Journal of Zoology 76: 62-69.

Bowers, M. A., and J. L. Dooley. 1999. A controlled, hierarchical study of habitat fragmentation: responses at the individual, patch, and landscape scale. Landscape Ecology 14: 381-389.

Bowman, J., N. Cappuccino, and L. Fahrig. 2002. Patch size and population density: the effect of immigration behavior. Conservation Ecology 6: 9-15.

Brown, A. L., and J. A. Litvaitis. 1995. Habitat features associated with predation of New England cottontails: what scale is appropriate? Canadian Journal of Zoology 73: 1005-1011.

Bruseo, J. A., S. H. Vessey, and J. S. Graham. 1999. Discrimination between Peromyscus leucopus noveboracensis and Peromyscus maniculatus nubiterrae in the field. Acta Theriologica 44: 151-160.

Burke, D. M., and E. Nol. 1998. Edge and fragment size effects on the vegetation of deciduous forests in Ontario, Canada. Natural Areas Journal 18: 45-53.

Collinge, S. K. 1996. Ecological consequences of habitat fragmentation: implications for landscape architecture and planning. Landscape and Urban Planning 36: 59-77.

Connor, E. F., A. C. Courtney, and J. M. Yoder. 2000. Individuals-area relationship: the relationship between animal population density and area. Ecology 81: 734-748.
Cummings, J. M., and S. H. Vessey. 1994. Agricultural influences on movement patterns of white-footed mice (Peromyscus leucopus). American Midland Naturalist 132: 209-218.

Diaz, M., T. Santos, and J. L. Telleria. 1999. Effects of forest fragmentation on the winter body condition and population parameters of a habitat generalist, the wood mouse Apodemus sylvaticus: a test of hypotheses. Acta Oecologica 20: 39-49.

Drickamer, L. C. 1990. Microhabitat preferences of two species of deermice (Peromyscus) in a northeastern United States deciduous hardwood forest. Acta Theriologica 35: 241-252.

Fahrig, L. 1997. Relative effects of habitat loss and fragmentation on population extinction. Journal of Wildlife Management 61: 603-610.

Fitzgibbon, C. D. 1997. Small mammals in farm woodlands: the effects of habitat, isolation and surrounding land-use patterns. Journal of Applied Ecology 34: 530-539.

Garcia, F. J., M. Diaz, J. M. de Alba, C. L. Alonso, R. Carbonell, M. L. de Carrion, C. Monedero, and T. Santos. 1998. Edge effects and patterns of winter abundance of wood mice (Apodemus sylvaticus) in Spanish fragmented forests. Acta Theriologica 43: 255-262.

Getz, L. L. 1961. Notes on the local distribution of Peromyscus leucopus and Zapus hudsonius. American Midland Naturalist 65: 486-500.

Gottschang, J. L. 1981. A guide to the mammals of Ohio. The Ohio State University Press, Columbus, Ohio, USA.

Harris, L. D. 1988. Edge effects and conservation biology. Conservation Biology 2: 330-332.

Henein, K., J. Wegner, and G. Merriam. 1998. Population effects of landscape model manipulation on two behaviourally different woodland small animals. Oikos 81: 168186.

Heske, E. J. 1995. Mammalian abundances on forest-farm edges versus forest interiors in southern Illinois: is there an edge effect? Journal of Mammalogy 76: 562-568.

Hutchinson, T. F., R. E. J. Boerner, L. R. Iverson, S. Sutherland, and E. K. Sutherland. 1999. Landscape patterns of understory composition and richness across a moisture and nitrogen mineralization gradient in Ohio (U.S.A.) Quercus forests. Plant Ecology 144: 177-189.

Kaufman, D. W., G. A. Kaufman, and E. J. Finck. 1995. Temporal variation in abundance of Peromyscus leucopus in wooded habitats of eastern Kansas. American Midland Naturalist 133: 7-17.

Kesner, M. H., and A. V. Linzey. 1997. Modeling population variation in Peromyscus leucopus: An exploratory analysis. Journal of Mammalogy 78: 643-654.

Kozakiewicz, M., T. Gortat, A. Kozakiewicz, and M. Barkowska. 1999. Effects of habitat fragmentation on four rodent species in a Polish farm landscape. Landscape Ecology 14: 391-400.

Krohne, D. T., and A. B. Burgin. 1990. Demographic heterogeneity in a population of Peromyscus leucopus. Oecologia 82: $97-101$.

Krohne, D. T., and G. A. Hoch. 1999. Demography of Peromyscus leucopus populations on habitat patches: the role of dispersal. Canadian Journal of Zoology 77: 1247-1253.

Lackey, J. A. 1978. Geographic variation in habitat use by the white-footed mouse, Peromyscus leucopus. American Midland Naturalist 100: 171-177.

Lewellen, R. H., and S. H. Vessey. 1998. Modeling biotic and abiotic influences on population size in small mammals. Oecologia 113: 210-218. 
Lidicker, W. Z., Jr., and N. C. Stenseth. 1992. To disperse or not to disperse: who does it and why? Pages 21-36 in Animal dispersal: small mammals as a model. Edited by N. C. Stenseth, and W. Z. Lidicker, Jr. Chapman \& Hall, New York, USA.

Manson, R. H., R. S. Ostfeld, and C. D. Canham. 1999. Responses of a small mammal community to heterogeneity along forest-old-field edges. Landscape Ecology 14: 355367.

Matlack, G. R. 1994. Vegetation dynamics of the forest edge - trends in space and successional time. Journal of Ecology 82: 113-123.

Matter, S. F., J. F. Zawacki, and M. A. Bowers. 1996. Habitat fragmentation and the perceived and actual risk of predation. Virginia Journal of Science 47: 19-27.

M'Closkey, R. T., and D. T. Lajoie. 1975. Determinants of local distribution and abundance in white-footed mice. Ecology 56: 467-474.

Moore, D. S., and G. P. McCabe. 1993. Introduction to the practice of statistics. W. H. Freeman and Co., New York. 854 pages.

Morris, D. W., and D. L. Davidson. 2000. Optimally foraging mice match use with habitat differences in fitness. Ecology 81: 2061-2066.

Mossman, C. A., and P. M. Waser. 2001. Effects of habitat fragmentation on population genetic structure in the whitefooted mouse (Peromyscus leucopus). Canadian Journal of Zoology 79: 285-295.

Murcia, C. 1995. Edge effects in fragmented forests: implications for conservation. Trends in Ecology and Evolution 10: $58-62$.

Nupp, T. E., and R. K. Swihart. 1996. Effect of forest patch area on population attributes of white-footed mice (Peromyscus leucopus) in fragmented landscapes. Canadian Journal of Zoology 74: 467-472.

Nupp, T. E., and R. K. Swihart. 1998. Effects of forest fragmentation on population attributes of white-footed mice and eastern chipmunks. Journal of Mammalogy 79: 1234-1243.

Parmenter, R. R., and J. A. MacMahon. 1983. Factors determining the abundance and distribution of rodents in a shrub-steppe ecosystem: the role of shrubs. Oecologia 59: $145-156$.

SAS. 1999-2000. SAS for Windows, SAS Institute, Inc.

Saunders, D. A., R. J. Hobbs, and C. R. Margules. 1991. Biological consequences of ecosystem fragmentation: a review. Conservation Biology 5: 18-32.

Schmid-Holmes, S., and L. C. Drickamer. 2001. Impact of forest patch characteristics on small mammal communities: a multivariate approach. Biological Conservation 99: 293-305.

Sokal, R. R., and F. J. Rohlf. 1981. Biometry: the principles and practice of statistics in biological research. W.H. Freeman and Co, San Francisco, California, USA. 859 pages.

Wegner, J., and G. Merriam. 1979. Movements by birds and small mammals between a wood and adjoining farmland habitats. Journal of Applied Ecology 16: 107-111.

Wegner, J., and G. Merriam. 1990. Use of spatial elements in a farmland mosaic by a woodland rodent. Biological Conservation 54: 263-276.

Wolf, M., and G. O. Batzli. 2001. Increased prevalence of bot flies (Cuterebra fontinella) on white-footed mice (Peromyscus leucopus) near forest edges. Canadian Journal of Zoology 79: 106-109.

Wolf, M., and G. O. Batzli. 2004. Forest edge: High or low quality habitat for white-footed mice (Peromyscus leucopus)? Ecology 85: 756-769.

Yahner, R. H. 1988. Changes in wildlife communities near edges. Conservation Biology 2: 333-339.

Received 13 May 2005

Accepted 12 December 2006 